\title{
Adrenoceptor-stimulated inflammatory response in stress-induced serum amyloid $A$ synthesis
}

\author{
Maria Konstandi ${ }^{1,2} \cdot$ Ioannis Sotiropoulos ${ }^{3,4} \cdot$ Tsutomu Matsubara $^{2,5} \cdot$ Foteini Malliou $^{1} \cdot$ Alexandra Katsogridaki $^{1}$. \\ Christina E. Andriopoulou ${ }^{1} \cdot$ Frank J. Gonzalez ${ }^{2}$
}

Received: 8 June 2018 / Accepted: 11 December 2018

(C) Springer-Verlag GmbH Germany, part of Springer Nature 2019

\begin{abstract}
Rationale Stressful life events are suggested to contribute to the development of various pathologies, such as cardiovascular disorders, whose etiopathogenesis is highly associated with elevated levels of serum amyloid A (SAA) proteins. SAA synthesis in the liver is regulated by a complex network of cytokines acting independently or in concert with various hormones/stimulants including the stress-activated sympathetic nervous system.

Objective This study aims to investigate the underlying mechanisms that regulate the stress-induced hepatic synthesis of SAA, with particular focus on adrenoceptors (AR), major components of the sympathoadrenal response to stress.

Methods and results We demonstrated that repeated stress elevates IL- $1 \beta$, IL- 6 , and TNF $\alpha$ serum levels in mice, accompanied by increased synthesis and secretion of hepatic SAA1/2 and SAA3, an effect that was blocked by AR antagonists. Moreover, stimulation of $\alpha_{1}$ - and $\beta_{1 / 2}$-ARs mimics the stress effect on SAA1/2 regulation, whereas $\alpha_{2}$-AR stimulation exhibits a relatively weak impact on SAA. In support of the essential cytokine contribution in the AR-agonist induced SAA production is the fact that the anti-inflammatory drug, sodium salicylate, prevented the AR-stimulated hepatic SAA1/2 synthesis by reducing IL- $1 \beta$ levels, whereas IL-1 $\beta$ inhibition with Anakinra mimics this sodium salicylate preventive effect, thus indicating a crucial role for IL-1 $\beta$. Interestingly, the AR-driven SAA3 synthesis was elevated by sodium salicylate in a TNF $\alpha$-dependent way, supporting diverse and complex regulatory roles of cytokines in SAA production. In contrast to $\alpha_{1} / \alpha_{2}$-AR, the $\beta_{1 / 2}$-AR-mediated SAA1/2 and SAA3 upregulation cannot be reversed by fenofibrate, a hypolipidemic drug with anti-inflammatory properties.

Conclusion Taken together, these findings strongly support a critical role of the AR-stimulated inflammatory response in the hepatic SAA production under stressful conditions, highlighting distinct AR type-specific mechanisms that regulate the hepatic synthesis of SAA1/2 and SAA3.
\end{abstract}

Keywords SAA1/2 $\cdot$ SAA $3 \cdot$ Stress $\cdot$ Adrenoceptors $\cdot$ IL- $1 \beta \cdot \mathrm{IL}-6 \cdot \mathrm{TNF} \alpha$

Electronic supplementary material The online version of this article (https://doi.org/10.1007/s00213-018-5149-4) contains supplementary material, which is available to authorized users.

Maria Konstandi

mkonstan@cc.uoi.gr

1 Faculty of Medicine, Department of Pharmacology, University of Ioannina, Ioannina, Greece

2 Laboratory of Metabolism, National Cancer Institute, National Institutes of Health, Bethesda, MD, USA

3 Life and Health Sciences Research Institute (ICVS), Medical School, University of Minho, Braga, Portugal

4 ICVS/3B's - PT Government Associate Laboratory, Braga, Portugal

5 Graduate School of Medicine, Department of Anatomy and Regenerative Biology, Osaka City University, Osaka, Japan

\section{Introduction}

Clinical and experimental evidence suggests that environmental stress and stressful life events contribute to the development of various pathologies whose aetiopathogenesis is highly associated with elevated levels of serum amyloid A (SAA) proteins (Dong et al. 2011; Marzi et al. 2013; Miyazaki et al. 2016; Ye and Sun 2015) (Johnson et al. 2004; O’Brien et al. 2005; Ridker et al. 1998). For instance, SAA mediates the retention of high- and low-density lipoproteins on vascular extracellular matrix and thus, favors atherogenesis by increasing cholesterol deposition in plaques; a condition associated with increased risk for cardiovascular disorders (Artl et al. 2000; Malle and De Beer 1996; O'Brien et al. 2005). Moreover, the longstanding overproduction of SAA is 
connected with the pathogenesis of systemic AA amyloidosis, which is found in chronic inflammatory, neoplastic, and infectious diseases. In systemic amyloidosis, the fibril proteins are alpha amyloid proteins (AA amyloids), formed by proteolytic splitting of SAA, and deposit in organs, such as the liver (Husebekk et al. 1985; Kisilevsky 1983; Pettersson et al. 2008; Skogen et al. 1980; Sletten and Husby 1974). It has been reported that excessive deposition of AA amyloids into systemic organs could result in organ failure or even become fatal (Jayaraman et al. 2017; Kingman and Pereira 2001; Nishi et al. 2008).

SAA proteins are secreted during the acute phase of inflammation and are considered as pleotropic. They serve several roles including the recruitment of immune cells to inflammatory sites, the activation of NF-kB and other transcription factors, the modification of the lifespan of neutrophils, the transport of cholesterol to liver and secretion to bile, as well as the induction of enzymes mediating the degradation of extracellular matrix (Ye and Sun 2015; Zhang et al. 2005). SAA1-SAA3 are the major acute phase reactants in mice (O'Brien et al. 2005; Zhang et al. 2005) synthesized in the liver and increased up to 1000-fold upon exposure to acute inflammatory stimulus (Lee et al. 2017; Malle and De Beer 1996; O'Brien et al. 2005; Steel and Whitehead 1994). The major stimulators of SAA synthesis in the liver are the pro-inflammatory cytokines, with interleukin $1 \beta$ (IL-1 $\beta$ ), hepatocyte stimulating factor/interleukin 6 (IL-6), and tumor necrosis factor alpha (TNF $\alpha$ ) being among the critical ones (Cray et al. 2013; Gabay and Kushner 1999; Jacobsen and Andersen 2007; Lee et al. 2017). Several diverse factors may regulate the immune response in humans and animals, with stress holding a critical role. Individuals exposed to stress show increased morbidity, which has been attributed, in part, to impaired function of their immune system (Chrousos 2009; Johnson et al. 1992). Previous studies demonstrated a cross-talk between the immune system and autonomous nervous system, with both the hypothalamic-pituitary-adrenal axis and the sympathetic nervous system (SNS) playing a critical role. Upon SNS activation by stress, catecholamines such as epinephrine and norepinephrine, are secreted from the adrenal medulla and sympathetic nerve terminals (Chrousos 2009; Johnson et al. 1992; Nicolaides et al. 2015) and induce their pleiotropic effects via stimulation of adrenoceptors (ARs). In particular, catecholamines target lymphocytes and phagocytes that express different ARs, thus triggering a general immune and pro-inflammatory mediator response (Johnson et al. 2005). Moreover, catecholamines are also secreted from these immune cells and act in an autocrine/paracrine fashion regulating phagocytes and affect lymphocyte trafficking and cytokine production, among others, via stimulation of $\alpha_{1} / \alpha_{2} / \beta_{2^{-}}$ ARs (Flierl et al. 2009; Nicolaides et al. 2015; Spengler et al. 1990, 1994; Tan et al. 2007).
However, the interplay of stress and in particular, of SNS in the immune response and SAA regulation, remains complex and poorly understood. For instance, previous studies report controversial evidence on the SNS effects on different components of the immune system (Elenkov et al. 2000; Flierl et al. 2009; Madden et al. 1989), while the role of stress on SAA regulation remains unclear, with several studies reporting either an up- or down-regulating stress-driven impact (Aich et al. 2009; McConnell et al. 2009). Therefore, the present study investigates the effect of stress, a major activator of SNS, on the regulation of SAA in the liver focusing on AR-linked pathways, major components of the sympathoadrenal response to stress (Cruise et al. 1987; Lalchandani et al. 2004; Minneman and Esbenshade 1994; Virtanen 1989).

\section{Materials and methods}

\section{Animals}

Male SV129 mice (9 weeks old) were housed in a temperature and light-controlled environment. Standard rodent chow and tap water were provided ad libitum. Animals were adapted to handling for an adaptation period of 1 week prior to the experiment. Ethics approval statement: all procedures were carried out in accordance with Institute of Laboratory Animal Resources (USA) guidelines and approved prior to the initiation of this study by the National Cancer Institute Animal Care and Use Committee. They also conformed to the International European Ethical Standards (86/609-EEC) for the care and use of laboratory animals.

\section{Stress paradigm}

In an isolated environment, experimental animals were exposed to restraint stress $2 \mathrm{~h}$ daily for 4 consecutive days (Konstandi et al. 2004). Throughout the stress, animals were restricted to adequately ventilated individual $50-\mathrm{mL}$ conical plastic tubes $(3 \times 10 \mathrm{~cm}$ modified Falcon tubes). During the stress task, no pain and physical squeezing were applied to the animals. They were allowed to rotate from supine to prone position, but they could not turn head to tail. Non-stressed controls were left undisturbed in their home cages, but food and water were removed for $2 \mathrm{~h}$ to match the stress group.

\section{Drugs and treatment}

The $\alpha_{1}$-AR agonist, phenylephrine hydrochloride (SigmaAldrich, $2 \mathrm{mg} / \mathrm{kg}$ ) and the $\beta_{1 / 2}$-AR agonist, isoprenaline hydrochloride (Sigma-Aldrich, $2 \mathrm{mg} / \mathrm{kg}$ ) were administered intraperitoneally for 4 consecutive days. The $\alpha_{2}$-AR 
agonist, dexmedetomidine hydrochloride (Dexdomitor, Orion Pharma-Pfizer, USA, $5 \mu \mathrm{g} / \mathrm{kg}$ ) was given subcutaneously for 4 consecutive days. The dose of dexmedetomidine was chosen in order to avoid sedation. Epinephrine (Sigma-Aldrich, $\alpha / \beta$-AR agonist) was administered daily for 4 consecutive days in the optimal dose $(0.5 \mathrm{mg} / \mathrm{kg}$, s.c.) to avoid cardiovascular implications. Prazosin hydrochloride $\left(\alpha_{1}\right.$-AR antagonist; SigmaAldrich, $20 \mathrm{mg} / \mathrm{kg}$ i.p) or atipamezole hydrochloride $\left(\alpha_{2}-\right.$ AR antagonist; Antisedan, Orion Pharma, Pfizer, $200 \mu \mathrm{g} / \mathrm{kg}$ s.c.), were administered $30 \mathrm{~min}$ prior to stress. Propranolol hydrochloride ( $\beta_{1 / 2}$-AR antagonist; SigmaAldrich, $10 \mathrm{mg} / \mathrm{kg}$, i.p.) was administered $15 \mathrm{~min}$ before stress. The dosages of the AR-agonists were selected according to the literature to achieve sufficient stimulation of the adrenoceptors (Virtanen 1989), while preserving all animals healthy throughout the experiment. Sodium salicylate (Sigma, $200 \mathrm{mg} / \mathrm{kg}$ i.p.) was administered $30 \mathrm{~min}$ before the AR-agonists. Mice also received Anakinra (IL-1 $\beta$ antagonist; Kineret, Sobi Swedish Orphan Biovitrum; total $300 \mathrm{mg} / \mathrm{kg}$ s.c.) prior to treatment with sodium salicylate and AR-agonists. More specifically, the treatment of mice started with Anakinra alone (100 mg/kg s.c.) in the morning, followed by $50 \mathrm{mg} / \mathrm{kg}$ s.c. Anakinra each time before the combined treatment containing sodium salicylate and AR agonist. Another group of animals was treated with Infliximab (TNF $\alpha$ inhibitor, Remicade, Centocor, USA; $10 \mathrm{mg} / \mathrm{kg}$ s.c., once daily, total $20 \mathrm{mg} / \mathrm{kg}$ ) administered $1 \mathrm{~h}$ before the first sodium salicylate injection of the day. Control animals of the last two experimental series received the vehicle containing $500 \mathrm{mg}$ sucrose, $0.5 \mathrm{mg}$ polysorbate$80,2.2 \mathrm{mg}$ monobasic sodium phosphate monohydrate, and $6.1 \mathrm{mg}$ dibasic sodium phosphate dihydrate per $10 \mathrm{~mL}$ sterile water. As sodium salicylate and all AR-agonists used in this study were dissolved in saline, all other controls received saline. Experimental animals were fed the normal diet. There were also animals treated with either normal saline (i.p.) or fenofibrate (FEN, in rodent chow $0.2 \%$ ), which also received the AR agonists. After the stress exposure and $2 \mathrm{~h}$ after the last drug-treatment, animals were killed by $\mathrm{CO}_{2}$ asphyxiation followed by decapitation. Trunk blood was collected in BD Microtainer Serum Separator Tubes (Becton, Dickinson and Company, USA) for hormonal, biochemical and western blot analyses and kept at $-80^{\circ} \mathrm{C}$. Liver samples were dissected for total RNA and cellular protein extraction.

\section{Quantitative real-time PCR}

TRIZOL reagent (Invitrogen, Carlsbad, CA) was used for isolation of total RNA from the tissues following the manufacturer's protocol. The concentration of total RNA was determined spectrophotometrically. Quantitative real-time reverse transcriptase PCR (qPCR) was performed with cDNA generated from $1 \mu \mathrm{g}$ total RNA with a SuperScript III reverse transcriptase kit (Invitrogen). Gene-specific primers were designed for qPCR using the Primer Express software (Applied Biosystems, Foster City, CA). Primer sequence $\left(5^{\prime}-3^{\prime}\right)$ : SAA1/2, forward: TCATGTCAGTGTAGGCTCGC, reverse: GTCTTCTGCTCCCTGCTCC; SAA3, forward: AGTAGGCTCGCCACATGTCT, reverse: TCCATTGC CATCATTCTTTG; and $\beta$-actin, forward: TATTGGCA ACGAGCGGTTCC, reverse: GGCATAGAGGTCTT TACGGATGTC. SYBR Green PCR master mix (Applied Biosystems, Warrington, UK) was used for the real-time reactions, which were carried out using the ABIPRISM 7900 HT sequence detection system (Applied Biosystems). The PCR conditions were the following: $95{ }^{\circ} \mathrm{C}$ for $10 \mathrm{~min}$ followed by 40 cycles of $95^{\circ} \mathrm{C}$ for $15 \mathrm{~s}$ and $60{ }^{\circ} \mathrm{C}$ for $1 \mathrm{~min}$, and 1 cycle of $95^{\circ} \mathrm{C}$ for $15 \mathrm{~s}, 60^{\circ} \mathrm{C}$ for $15 \mathrm{~s}$, and $95^{\circ} \mathrm{C}$ for $15 \mathrm{~s}$. Relative mRNA expression levels were normalized to $\beta$-actin and values were quantified using the comparative threshold cycle method.

\section{Western blot analysis}

Immunoblot analysis of SAA proteins was carried out using serum samples from the treated animals. Serum samples were subjected to fragmentation using specific nanofilters (Pall Nanosep Omega 30K PK100, Utech Products Inc. Schenectady, NY), which removed proteins with molecular weight higher than $30 \mathrm{kDa}$. Protein concentrations were determined with a BCA protein assay kit (Pierce, Rockford, IL). Proteins separated by sodium dodecyl sulfate-polyacrylamide gel $(15 \%)$ electrophoresis were transferred overnight $\left(100 \mathrm{~mA}\right.$ at $\left.4{ }^{\circ} \mathrm{C}\right)$ to polyvinylidene difluoride membranes (GE Healthcare, Piscataway, NJ). Membranes were blocked in 3\% non-fat milk in Tris-buffered saline (TBS)-Tween buffer for $1 \mathrm{~h}$. Blocked membranes were incubated in rat monoclonal $\mathrm{IgG}_{2 \mathrm{~b}}$ specific for mouse SAA antibody (1:200; sc59,680; Santa Cruz Biotechnology, Santa Cruz, CA). The expressions of the phospho, as well as total protein levels of kinase Akt and the extracellular signal-regulated kinase (Erk1/2) were analyzed in liver protein extracts using RIPA buffer supplemented with protease inhibitors, PMSF $(10 \mu \mathrm{M})$, BGP $(50 \mu \mathrm{M})$, and $\mathrm{NaF}(50 \mu \mathrm{M})$. Total extracts were subjected to sodium dodecyl sulfatepolyacrylamide gel $(7 \%)$ electrophoresis and immunoblotting using the phosphor and total Akt, Erk1/2 antibodies (1:500 and 1:1000, respectively; Cell Signaling). Immunoblotting with GAPDH antibody (1:1000, Santa Cruz Biotechnology) was used as loading control. After incubation with the appropriate secondary antibody (Cell Signaling), antigens were revealed by enhanced chemiluminescence detection kit (ECL Clarity, Bio-Rad). Signal 
monitoring and quantification were achieved using a BIORAD ChemiDoc and ImageLab BIORAD software. All values were normalized and expressed as a percentage of control values.

\section{Hormonal and biochemical determinations}

Serum IL-1 $\beta$, IL- 6 , and TNF $\alpha$ levels were determined using IL- $1 \beta$ EIA (R\&D Systems, Minneapolis, MN), IL6 EIA (eBioscience Ready-SET-Go, San Diego, USA) and TNF $\alpha$ OptEIA EIA (BD Biosciences-Pharmingen) kit assays, respectively. To assess the possible toxic effects of the AR-agonists, serum ALT and AST levels were measured with the DiscretePak ALT and AST Reagent kits (Catachem Inc., Bridgeport, CT), respectively. As a key element of the neuroendocrine response to stress (Chrousos 2009; Johnson et al. 1992), corticosterone (CORT) levels were measured using a Corticosterone EIA kit (Cayman Chemical Company, Ann Arbor, MI) and found ranging from 30 to $100 \mathrm{pg} / \mathrm{mL}$ in non-stressed controls and 160 to $300 \mathrm{pg} / \mathrm{mL}$ in stress-exposed mice (mean \pm SE; control vs. stress, $87.0 \pm 21.3$ vs. $226 \pm 40.0$, $n=20, P<0.001)$. The detection limit was about $40 \mathrm{pg} / \mathrm{mL}$ and the intra-assay coefficient of variation (CV) was $4.1 \%$. Monitored by RapiTex CRP kit assay (Siemens), serum Creactive protein (CRP) levels were not significantly altered by repeated stress or AR agonists. In all treatment groups, CRP values raged at levels lower than $6 \mu \mathrm{g} / \mathrm{mL}$ (no agglutination was observed).

\section{Statistical analysis}

All data are presented as the mean $\pm \mathrm{SE}$ and were analyzed using one-way analysis of variance (ANOVA) followed by Bonferroni's or Tukey's post hoc analysis. Correlation analysis (see Table 1) was performed using the Pearson's coefficient correlations. The significance level for all analyses was set at probability of less than 0.05 .

Table 1 Correlation between liver SAA expression and serum cytokine levels

\begin{tabular}{|c|c|c|c|}
\hline Variables & IL-1 $\beta$ & IL-6 & $\mathrm{TNF} \alpha$ \\
\hline \multicolumn{4}{|c|}{ Comparison: $C o n$ vs. $P h$ ( $\alpha_{1}$-AR agonist) } \\
\hline $\mathrm{SAA} 1 / 2$ & $0.82 *$ & $0.79 *$ & $0.78 *$ \\
\hline SAA3 & $0.86^{*}$ & $0.82 *$ & $0.87 *$ \\
\hline \multicolumn{4}{|c|}{ Con vs. Dext ( $\alpha_{2}$-AR agonist) } \\
\hline SAA1/2 & 0.22 & 0.23 & 0.12 \\
\hline SAA3 & 0.16 & 0.12 & 0.01 \\
\hline \multicolumn{4}{|c|}{ Con vs. Isop ( $\beta_{1 / 2}$-AR agonist $)$} \\
\hline $\mathrm{SAA} 1 / 2$ & $0.73^{*}$ & $0.78 *$ & $0.95 *$ \\
\hline SAA3 & $0.83 *$ & $0.80 *$ & $0.93 *$ \\
\hline
\end{tabular}

\section{Results}

\section{Exposure to repeated stress increases SAA synthesis: role of adrenoceptor-linked pathways}

To evaluate the impact of psychophysiological stress on SAA synthesis, mice were exposed to repeated restraint stress. We found that repeated stress markedly increased mRNA levels of SAA1/2 and SAA3 isoforms in the liver of animals where these proteins are predominantly produced (Uhlar and Whitehead 1999) (Fig. 1a, b). Furthermore, western blot analysis revealed that restraint stress also increased total SAA protein load in the serum (Fig. 1c, d), an effect that was accompanied by elevated IL- $1 \beta$, IL-6, and TNF $\alpha$ serum levels when compared to non-stressed controls (Fig. 1e). Along with glucocorticoids, catecholamines released upon stress represent the major elements of the stress response (Chrousos 2009; Johnson et al. 1992; Nicolaides et al. 2015) and display their properties by activation of $\alpha$ - and $\beta$-adrenoceptors (ARs) (Cooper and Bloom 1996). To identify the role of catecholamines and $\alpha_{1^{-}}, \alpha_{2^{-}}$, and $\beta_{1 / 2^{-}}$AR in the regulation of SAA, we next treated animals with epinephrine (Epin, $\alpha / \beta$-AR agonist) or agonists of different ARs. As shown in Fig. 2, Epin treatment upregulated SAA1/2 and SAA3 in the liver (Fig. 2a, b) and increased the load of SAA in the serum (Fig. 2c) followed by increased IL- $1 \beta$, IL- 6 , and TNF $\alpha$ serum levels compared to controls (Table 2). Treatment with either phenylephrine (Ph), an $\alpha_{1}$-AR agonist, or isoprenaline (Isop), a $\beta_{1 / 2^{-}}$ AR agonist increased $S A A 1 / 2$ and $S A A 3$ mRNA expression in the liver of mice, and elevated total SAA protein load in serum, when compared to controls (Fig. 2a-d), mimicking the effects of repeated stress (compare with Fig. 1). It should be noted that, although dexmedetomidine (Dext), an $\alpha_{2}$-AR agonist, markedly increased $S A A 1 / 2$ and $S A A 3$ mRNA expression in the liver of mice, no such effect was detected at total SAA protein load in the serum (Fig. 2c, d). Furthermore, $\mathrm{Ph}$ and Isop $\left(\alpha_{1-}\right.$ and $\beta_{1 / 2}-\mathrm{AR}$ agonist, respectively) triggered a marked increase in serum IL-1 $\beta$, IL-6, and TNF $\alpha$ levels (Table 2) that was statistically correlated with SAA1/2 and SAA3 mRNA levels (Table 1$)$. Note that Dext $\left(\alpha_{2}\right.$-AR agonist) exhibited a mild effect on the above cytokines that was not correlated with SAA levels (Tables 1 and 2). Combined with the weaker effect of Dext on $S A A 1 / 2$ and $S A A 3$ mRNA expression, these findings suggest that stimulation of $\alpha_{2}$-AR alone is not able to trigger markedly SAA production and secretion.

As the above findings clearly demonstrated the driving role of different ARs in hepatic SAA synthesis and secretion, we next investigated the involvement of AR-linked pathways in the stress-induced SAA upregulation by treating mice with either $\alpha$ - or $\beta$-AR-antagonists prior to stress exposure. We found that blockade of either $\alpha_{1^{-}}, \alpha_{2^{-}}$, or $\beta_{1 / 2}$-ARs with prazosin (Pz), atipamezole (Ati), or propranolol (Prop), 
Fig. 1 Repeated restraint stress triggers the induction and release of serum amyloid proteins. a-d Animals exposed to repeated restraint stress (Str) exhibited higher hepatic mRNA levels of serum amyloid A1/2 (SAA1/2) (a), serum amyloid A3 (SAA3) (b), as well as higher serum SAA apoprotein levels (c, d) compared to undisturbed control animals (Con). e In parallel, serum cytokine levels, interleukin $1 \beta$ (IL-1 $\beta$ ), interleukin 6 (IL-6), and tumor necrosis factor $\alpha(\mathrm{TNF} \alpha)$, were markedly increased in the stressed animals compared to controls. All numerical data are shown as mean + SEM; $* P<0.05, * * P \overline{<} 0.01$, $* * * P<0.001$

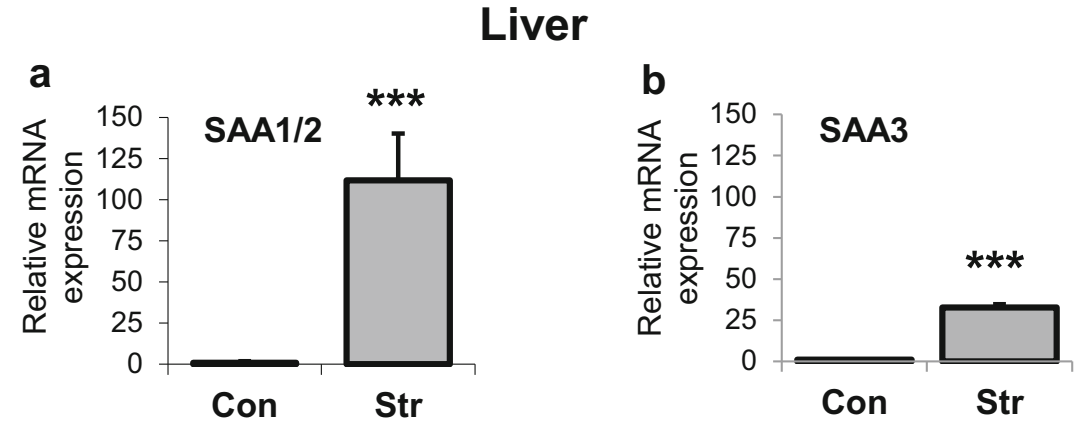

Serum
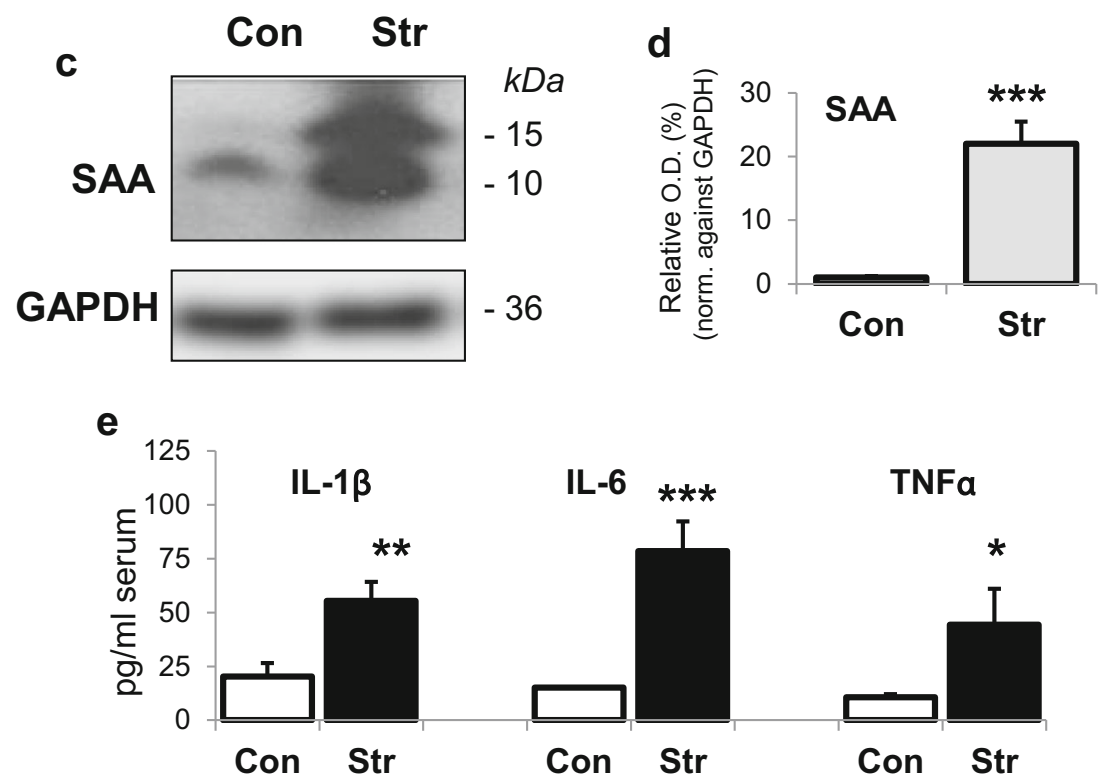

respectively, prior to stress, prevented the upregulating effect of stress on SAA1/2 (Fig. 2e). Interestingly blockade of either $\alpha_{2}$ or $\beta_{1 / 2}$-ARs alone by Ati or Prop, respectively, prevented the upregulating effect of stress on SAA3, whereas blockade of $\alpha_{1}$-AR with Pz did not prevent it (Fig. 2f). Thus, the above findings indicated that the stress-induced SAA1/2 upregulation is mediated by stimulation of all types of ARs (Fig. 2e), whereas that of SAA3 is mediated mainly by $\alpha_{2}$ and $\beta_{1 / 2}$-AR stimulation (Fig. 2f). It should be noted that the effect of ARagonists on SAA synthesis is not related to any toxic effect, as AST and ALT serum levels were not significantly modified by the drugs used (Supplementary Table 1).

\section{Dissecting the inflammatory signals in adrenoceptor-mediated SAA up-regulation}

To further assess the involvement of cytokines in the ARmediated upregulation of SAA, a different group of animals was simultaneously treated with AR agonists and the nonsteroidal anti-inflammatory drug, sodium salicylate, known to reduce pro-inflammatory cytokine synthesis in macrophages (Housby et al. 1999; Vittimberga Jr. et al. 1999) and to inhibit the production of COX2/PG/PKA, downstream elements in IL-1 $\beta$-related pathways (Schiller et al. 2006). As shown in Fig. 3, sodium salicylate prevented the $\alpha_{1^{-}}, \alpha_{2^{-}}$, and $\beta_{1 / 2^{-}}$AR induced hepatic SAA1/2 upregulation (Fig. 3a) that was accompanied by suppression of serum IL$1 \beta$ levels (Fig. 3b); note that serum IL-6 levels remained unaffected [Ph vs. ( $\mathrm{Ph}+$ sodium salicylate), $107.6 \pm 19.6$ vs. $103.0 \pm 32.1, n=10]$. In order to clarify the potential role of IL-1 $\beta$, we next investigated the effect of Anakinra, an IL-1 $\beta$ inhibitor, which blocked the AR agonist-induced SAA1/2 upregulation (Fig. 3c), confirming the critical role of IL-1 $\beta$ in the AR-induced SAA1/2 upregulation.

Interestingly, sodium salicylate exhibited a different effect on SAA3 synthesis when administered in combination with AR agonists. Specifically, the combined treatment with sodium salicylate and $\mathrm{Ph}\left(\alpha_{1}-\mathrm{AR}\right.$ agonist) resulted in a robust increase in hepatic $S A A 3$ mRNA levels (Fig. 3d), which could be related to the increased serum TNF $\alpha$ levels detected in this treatment group (Fig. 3e). In support of this notion, cotreatment of $\mathrm{Ph}+$ sodium salicylate with the TNF $\alpha$ inhibitor 

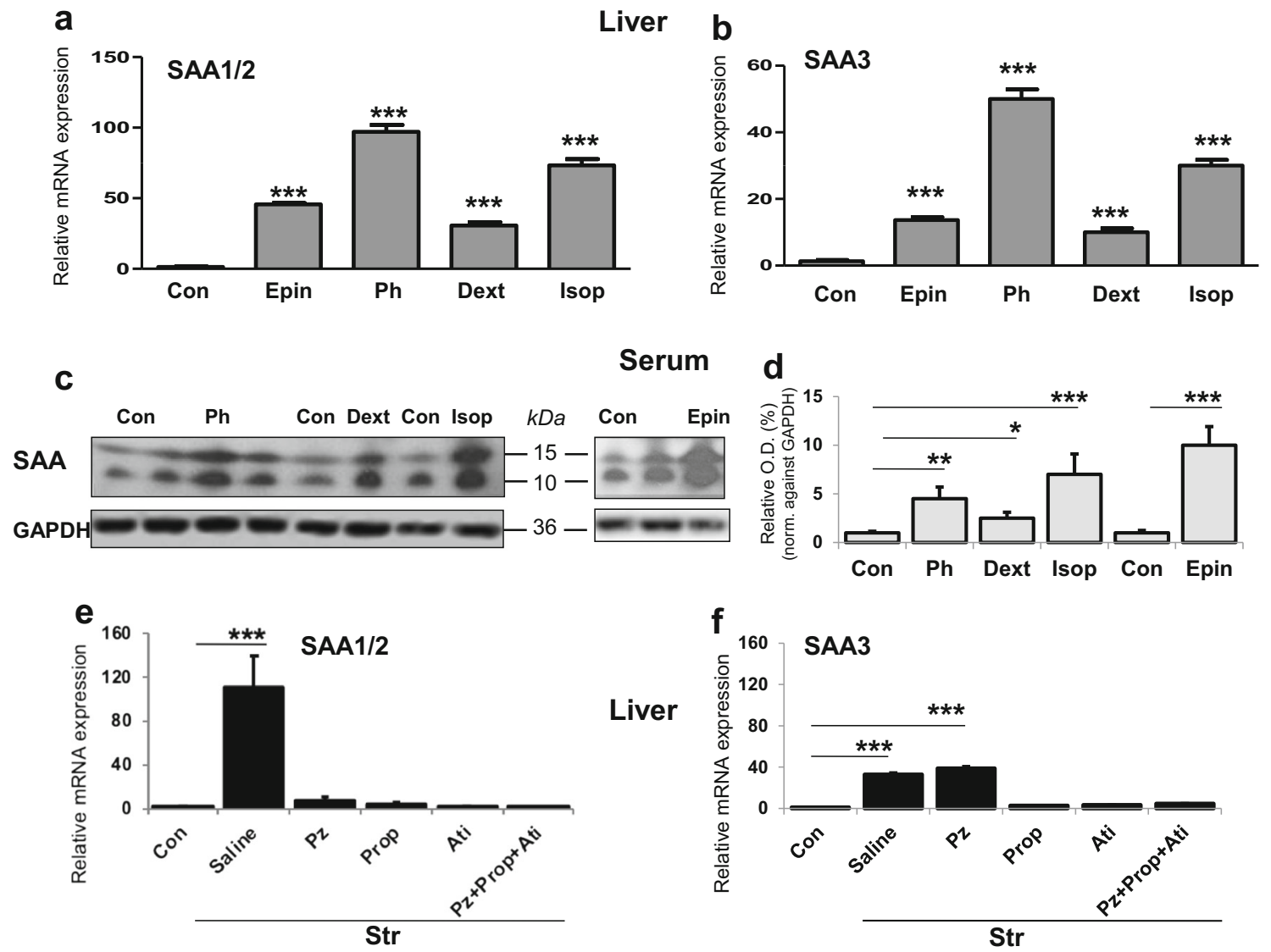

Fig. 2 Role of adrenergic receptors in serum amyloid A (SAA) regulation under control and stressful conditions. a-d Epinephrine (Epin) treatment increased hepatic $S A A 1 / 2$ and $S A A 3$ mRNA levels, while pharmacological stimulation of $\alpha_{1}$ - or $\beta_{1 / 2}$-adrenergic receptors (AR) by phenylephrine $(\mathrm{Ph})$ or isoprenalin (Isop) $\left[\alpha_{1}\right.$ - and $\beta_{1 / 2}$-AR agonist, respectively) also triggered the induction of SAA1/2 and SAA $3(\mathbf{a}, \mathbf{b})$. Similarly, the serum SAA apoprotein load was also increased by Epin, $\mathrm{Ph}$, and Isop (c, d). Note that the stimulation of $\alpha_{2}$-AR by dexmedetomidine (Dext) also triggered the induction of $S A A 1 / 2$ and $S A A 3$ mRNA expression in the

liver, but to a lesser extent. e, f Treatment of animals with AR-antagonists prior to stress [prazosin (Pr), $\alpha_{1}$-AR antagonist; propranolol (Prop), $\beta_{1 / 2^{-}}$ AR antagonist; atipamezole (Ati). $\alpha_{2}$-AR antagonist] blocked the stressdriven increase of hepatic $S A A 1 / 2$ mRNA levels, while in contrast to $\beta_{1 / 2^{-}}$ and $\alpha_{2}$-AR antagonists, single treatment with $\operatorname{Pr}$, the $\alpha_{1}$-AR antagonist, did not block the stress-evoked increase of $S A A 3$ mRNA levels. All numerical data are shown as mean $\pm \mathrm{SEM} ; * P<0.05, * * P<0.01$, $* * * P<0.001$

(Infliximab) prevented the robust upregulation of hepatic SAA3 mRNA levels (Fig. 3f). Co-treatment of sodium salicylate with Dext or Isop ( $\alpha_{2}$ - and $\beta_{1 / 2}$-AR agonist, respectively) also increased hepatic $S A A 3$ mRNA levels, but to a lesser extent (Fig. 3d), and this upregulation appears to be associated with the increased serum TNF $\alpha$ levels (Fig. 3e, f). In order to further investigate the pathways underlying the sodium salicylate-induced blockade of the AR-stimulated $S A A 1 / 2$

expression, we also monitored the activation of Akt and Erk $1 / 2$ signaling pathways that regulate SAA synthesis (Fasshauer et al. 2004; Nguyen and Gao 1999). Western blot analysis revealed that $\mathrm{Ph}$ alone reduced the levels of phosphorylated Akt (p-Akt), while Isop had no effect (Fig. 3g, h). Interestingly, when sodium salicylate was provided alone, it also decreased p-Akt levels. However, in presence of Isop, sodium salicylate increased Akt phosphorylation, an effect

Table 2 The impact of epinephrine and different adrenoceptor agonists on serum cytokine levels

\begin{tabular}{lccc}
\hline Repeated treatment & IL-1 $\beta$ & IL-6 & TNF $\alpha$ \\
\hline Control & $20.0 \pm 4.4$ & $27.6 \pm 5.3$ & $11.3 \pm 1.3$ \\
Epin $(\alpha / \beta$-AR agonist $)$ & $102 \pm 18.1^{* * *}$ & $50.6 \pm 8.2^{* *}$ & $390 \pm 186.9 * *$ \\
Ph $\left(\alpha_{1}\right.$-AR agonist $)$ & $100 \pm 13.8^{* * *}$ & $107.6 \pm 19.6^{* * *}$ & $261 \pm 54.8^{* * *}$ \\
Dext $\left(\alpha_{2}\right.$-AR agonist $)$ & $50.6 \pm 12.6^{* *}$ & $48.0 \pm 7.4 * *$ & $15.0 \pm 2.9$ \\
Isop $\left(\beta_{1 / 2}\right.$-AR agonist $)$ & $124 \pm 5.0^{* * *}$ & $44.5 \pm 1.4 * * *$ & $179 \pm 60.6^{* * *}$ \\
\hline
\end{tabular}




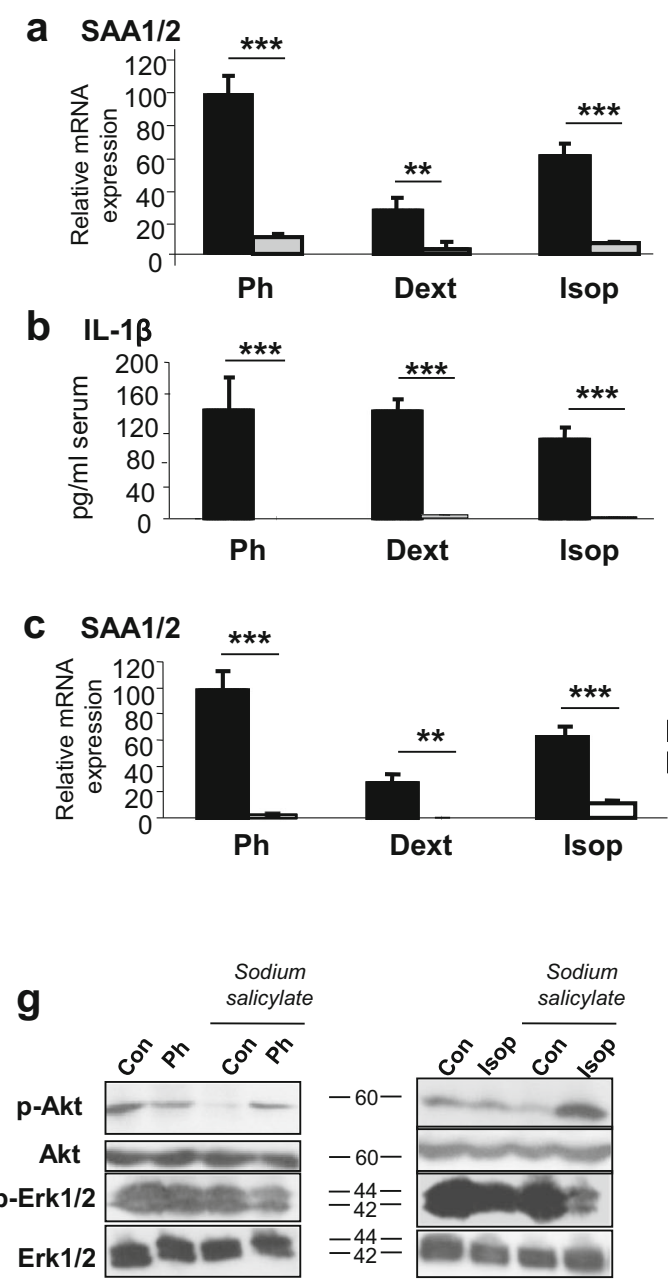

Liver

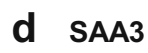

Serum

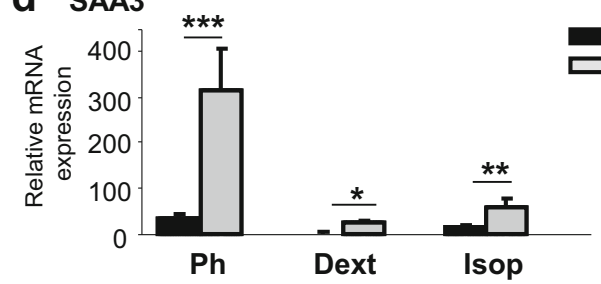

e TNFa

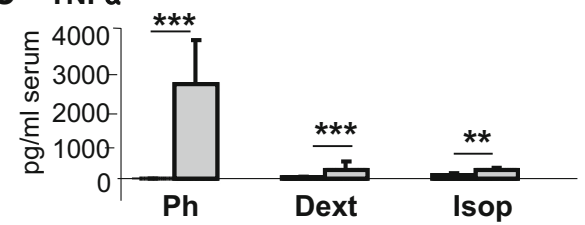

Liver

Vehicle

Anakinra

(IL-1 $\beta$ inh)

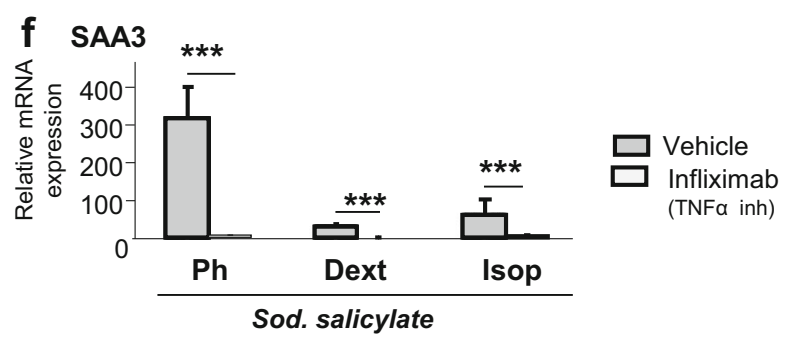

h
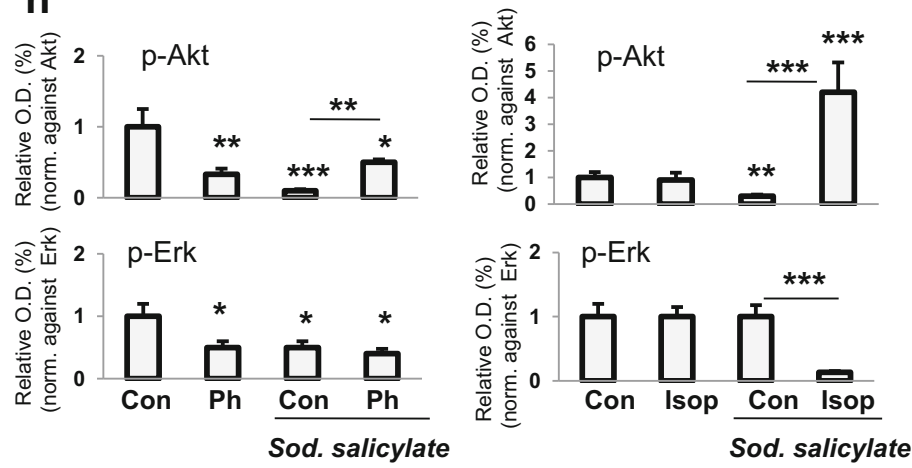

Fig. 3 Differential impact of sodium salicylate in the AR-driven hepatic SAA1/2 and SAA3 synthesis. a-c Pre-treatment of mice with sodium salicylate (Sod. salicylate) prevented the AR-induced increase of hepatic $S A A 1 / 2$ mRNA levels, which was evoked by different AR agonists, such as $\mathrm{Ph}$, Dext, and Isop (a). Sod. salicylate prevented the remarkable ARinduced increase of serum IL-1 $\beta$ levels (b). The IL- $1 \beta$ inhibitor, Anakinra, also blocked the AR-agonist induced hepatic SAA1/2 induction supporting a role for IL-1 $\beta$ in this AR-evoked SAA1/2 induction (c). d-f In contrast to SAA1/2 effect, sod. salicylate markedly increased the AR agonist triggered SAA3 induction; note that the higher effect of sod. salicylate on SAA3 mRNA levels was found in animals following pharmacological stimulation of their $\alpha_{1}$-AR with $\mathrm{Ph}(\mathbf{d})$. In parallel, sod.

that is potentially associated with the SAA $1 / 2$ downregulation that was observed in mice of this treatment group (see Fig. 3a). A clearly different profile of sodium salicylate effect on Erk1/ 2 phosphorylation (p-Erk1/2 levels) was found. In particular, sodium salicylate did not alter the $\mathrm{Ph}$-induced reduction of Erk1/2 phosphorylation, while it strengthened that of Isop (Fig. 3g, h; Supplementary Fig. 1). salicylate, boosted TNF $\alpha$ serum levels, especially in the Ph-treated animals (e), whereas pre-treatment with the TNF $\alpha$ inhibitor, Infliximab, completely blocked the sod. salicytate-driven increase of $S A A 3 \mathrm{mRNA}$ levels. These findings support the essential role of TNF $\alpha$ in SAA3 regulation (f). g, h Western blot analysis of the hepatic p-Akt and p-Erk1/2 upon treatment with $\mathrm{Ph}$ or Isop in the presence or absence of sod. salicylate $(\mathbf{g})$. Treatment with sod. salicylate increased p-Akt in the liver of mice following $\mathrm{Ph}\left(\alpha_{1}\right.$-AR agonist) or Isop ( $\beta_{1 / 2}$-AR agonist) treatment (h). No effect of sod. salicylate was found on p-Erk1/2 levels in mice following $\mathrm{Ph}$ treatment, but there was a sod. salicylate-driven reduction in hepatic p-Erk $1 / 2$ of mice upon Isop treatment. All numerical data are shown as mean \pm SEM; $* P<0.05, * * P<0.01, * * * P<0.001$

\section{Fenofibrate-induced blockade of the adrenoceptor-mediated SAA upregulation}

As previous studies have reported the involvement of peroxisome proliferator-activated receptor $\alpha(\operatorname{PPAR} \alpha$, negative regulator of inflammatory response) in SAA production (Gervois et al. 2004; Yamazaki et al. 2002); (Delerive et al. 1999; Staels 
et al. 1998), we next investigated the impact of fenofibrate (FEN), a PPAR $\alpha$-agonist with anti-inflammatory properties (Won 2013), on AR-driven SAA regulation. We found that, when administered simultaneously with Ph or Dext $\left(\alpha_{1}\right.$ - and $\alpha_{2}$-AR agonist, respectively), FEN prevented the AR agonistinduced upregulation of SAA $1 / 2$ and SAA 3 in the liver (Fig. 4a, b). Furthermore, this FEN inhibiting effect was accompanied by marked reduction of IL- $1 \beta$ serum levels (Fig. 4c). Pearson's coefficient correlation showed that this FEN-induced blockade is highly correlated with serum IL$1 \beta$ and IL-6 levels $\left(R^{2}=0.883\right.$ and 0.834 , respectively,
$P<0.001)$. However, FEN was unable to block the Isop ( $\beta_{1 / 2}-A R$ agonist)-induced upregulation of SAA $1 / 2$ and SAA3 (Fig. 4a, b) suggesting that the protective role of FEN against the AR-mediated upregulating effect on SAA does not include that of $\beta_{1 / 2}$-ARs. On the other hand, serum TNF $\alpha$ levels were markedly increased in mice treated with both, $\mathrm{Ph}$ and FEN, compared to mice treated with $\mathrm{Ph}$ alone (Fig. 4d). Nonetheless, it is of interest to note that, whereas IL-1 $\beta$ and TNF $\alpha$ serum levels were markedly decreased by FEN in mice treated with Isop when compared to those treated with Isop alone (Fig. 4c, d); apparently, FEN did not manage to block
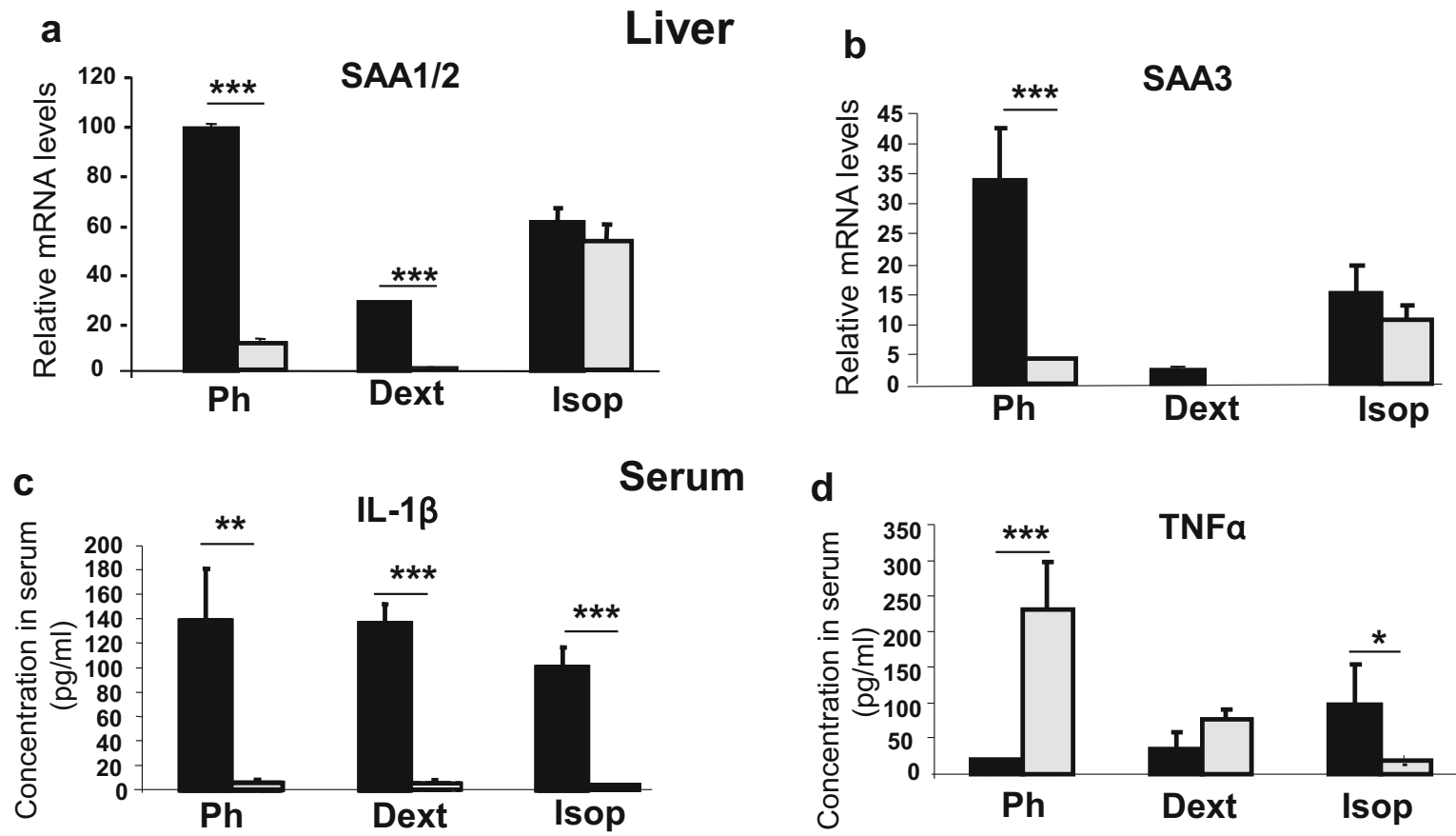

Serum
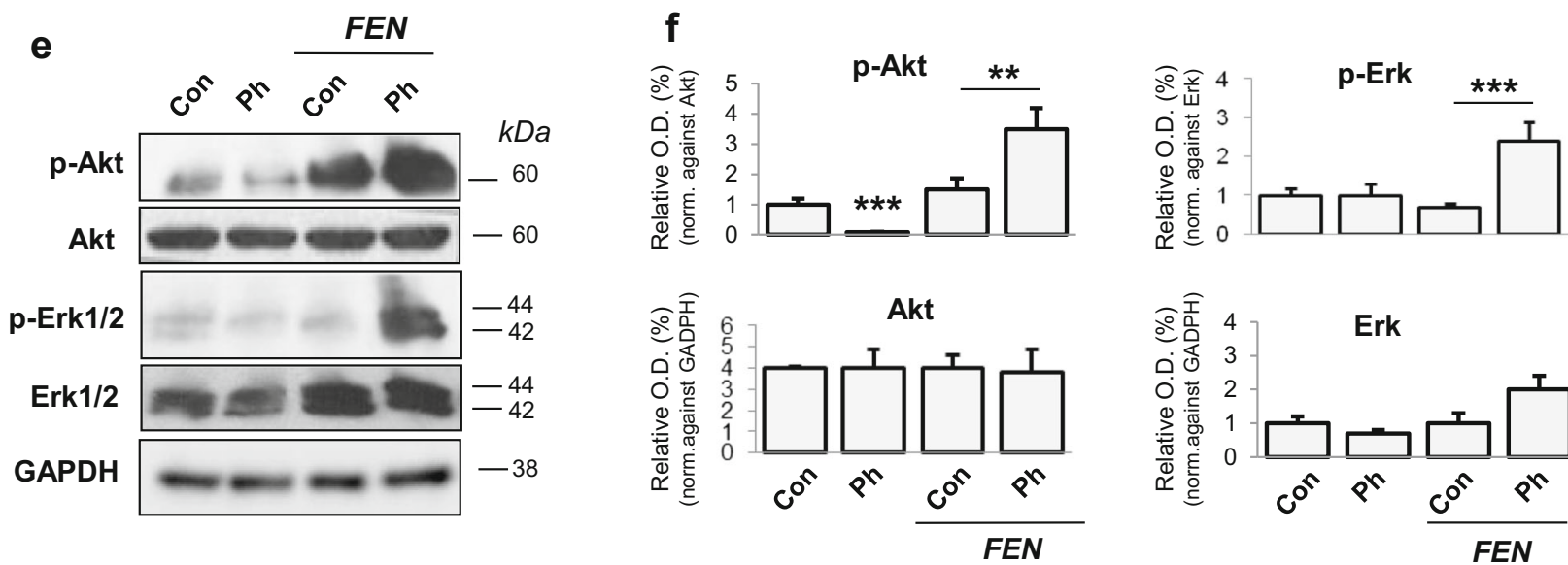

Fig. 4 Fenofibrate blocked the AR-stimulated SAA induction. a, b Pre-treatment with Fenofibrate (FEN) has blocked the hepatic induction of $S A A 1 / 2$ and $S A A 3$ mRNA expression by $\alpha_{1-}$ and $\alpha_{2}$-AR agonists, but not that by $\beta_{1 / 2}$-AR agonists. c, d The increase of serum IL- $1 \beta$ levels induced by all three types of AR agonists was blocked by FEN treatment (c). In contrast, the FEN-driven blockade of the AR-triggered SAA3 induction was accompanied by increased

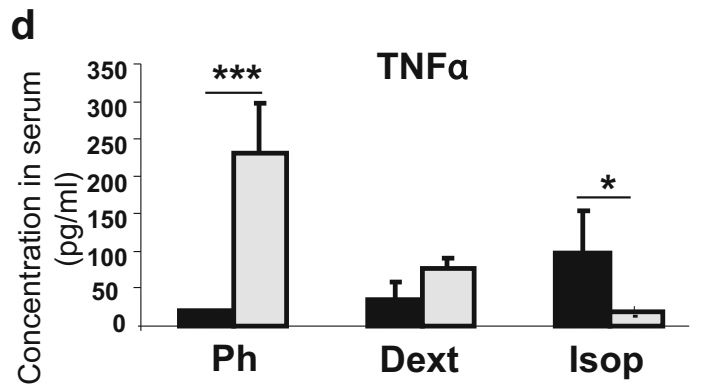

$\mathrm{TNF} \alpha$ serum levels in mice under Ph treatment, and reduced TNF $\alpha$ serum levels in those under Isop treatment (d). e, f Western blot analysis showed that FEN increased the hepatic pAkt and pErk1/2 levels in mice following $\mathrm{Ph}$ treatment, while no effect was found in total Akt and Erk levels. All numerical data are shown as mean $\pm \mathrm{SEM} ; * P<0.05, * * P<0.01, * * * P<0.001$ 
the Isop-driven increase in SAA1/2 and SAA3 production. These findings profoundly exclude a PPAR $\alpha$ involvement in the $\beta_{1 / 2}$-AR-induced SAA1/2 and SAA3 synthesis (Fig. $4 \mathrm{a}$, b). Furthermore, it was found that the combined treatment of FEN and $\mathrm{Ph}$, markedly increased the phosphorylated levels of Erk1/2 and Akt (Fig. 4e, f), suggesting an involvement of these negative regulators in the FEN-mediated blockade of the Ph-induced $S A A 1 / 2$ mRNA expression (Fig. 4a).

\section{Discussion}

There is an increasing body of evidence supporting that the dynamic equilibrium between immune system and CNS is regulated by autonomic pathways with catecholamines holding key roles (Flierl et al. 2009; Sternberg 2006; Tracey 2002). Accordingly, activation of SNS by stress or different drugs could target immune cells (e.g., macrophages) that express all types of ARs. The present findings are in line with those of previous studies indicating the up-regulating effect of stress on SAA (Bryleva et al. 2017; Collier et al. 2011; Turlo et al. 2015). They further support the involvement of different ARs in the stress-driven synthesis of both SAA1/2 and SAA3 in the liver, while total serum SAA protein load was also increased, indicating an AR-mediated systemic increase of these acute phase proteins. Previous studies indicated that catecholamines released by stress regulate the inflammatory potential of the immune cells by stimulating ARs and thus, triggering the secretion of IL-1 $\beta$, IL-6, and TNF $\alpha$ (Flierl et al. 2007, 2008, 2009). Therefore, the afore-mentioned increase in SAA synthesis in the liver could be attributed to the AR-stimulated cytokine release from the immune cells, such as macrophages (Ghezzi and Sipe 1988; O’Brien et al. 2008)—see also Fig. 5). This notion is further supported by the fact that direct stimulation of hepatocyte AR signaling pathways, using primary hepatocyte cultures treated with AR agonists, did not affect $S A A 1 / 2$ and $S A A 3$ expression (data not shown). Nonetheless, the contribution of hepatic AR-linked pathways should not be excluded as the molecular chaperons, ApoE and $\alpha 1$ antichymotrypsin, participating in the formation of amyloid proteins, are missing from primary hepatocyte cultures (Ma et al. 1994).

Furthermore, aiming to dissect the potentially differential role of various ARs in the regulation of synthesis and secretion of SAA1/2 and SAA3 proteins, this study suggests that, despite the fact that the stress-driven SAA1/2 production requires all three types of ARs monitored in this study $\left(\alpha_{1^{-}}\right.$, $\alpha_{2^{-}}, \beta_{1 / 2}$-ARs), only the $\alpha_{2^{-}}$and $\beta_{1 / 2}$-AR driven pathways appear to regulate the stress-evoked SAA3 synthesis (see Fig. 2e, f). Furthermore, pharmacological activation of distinct ARs also mimic, at least in part, the stress-triggered hepatic production of SAA1/2 and SAA3 supporting their potential contribution to SAA regulation. In this set of experiments investigating the impact of distinct $\mathrm{AR}$ type activation on SAA production, $\alpha_{1}$ - and $\beta_{1 / 2}$-AR exhibited a stronger effect than that of $\alpha_{2}$-AR. It is noteworthy that during stress, adrenaline and noradrenaline are released and stimulate all types of ARs. It is known that $\alpha_{2}$-AR stimulation (by an agonist) results in inhibition of noradrenaline release and therefore, to reduced stimulation of post-synaptic $\alpha_{1^{-}}$and $\beta_{1 / 2}$-ARs (Cooper and Bloom 1996; Furchgott 1972; Langer 2015; Lohse 2015; Fabbri and Moon 2016). On the contrary, $\alpha_{1^{-}}$ and $\beta_{1 / 2}$-AR agonists directly stimulate the post synaptic ARs. Furthermore, the $\alpha_{2}$-ARs expressed on hepatic cell membranes are linked to Gi proteins and inhibit the cAMP/PKA/CREB signaling pathway, whereas the $\alpha_{1-}$ and $\beta_{1 / 2}$-ARs are linked to Gs proteins and stimulate this pathway, thus differently affecting SAA synthesis (Barneda-Zahonero et al. 2009).

The present findings suggest a potential strong role for the AR-triggered inflammatory response in SAA regulation. Specifically, the AR-mediated SAA1/2 upregulation was prevented by sodium salicylate (a non-steroidal anti-inflammatory drug), that could be attributed to the suppression of various cytokines (e.g., IL-1 $\beta$ ); this effect was highly correlated to hepatic $S A A 1 / 2$ expression. The critical role of IL- $1 \beta$ in the AR-agonist-induced SAA1/2 upregulation was also demonstrated using Anakinra (IL-1 $\beta$ inhibitor), which blocked the upregulation of SAA1/2 triggered by all three types of ARs. In contrast to IL6, the $\alpha_{1}$-AR-driven increase of IL-1 $\beta$ (Ph treatment) was prevented by sodium salicylate, a fact that further supports the direct involvement of IL-1 $\beta$, but not that of IL- 6 , in the $\alpha_{1}$-AR-driven SAA1/2 synthesis (see Fig. 5).

Fibrates, such as fenofibrate, are hypolipidemic drugs, widely used in lowering plasma triglyceride and cholesterol levels in patients with hyperlipidemias (Gervois et al. 2004; Yamazaki et al. 2002). Often, these patients suffer from cardiovascular disorders and are treated with drugs targeting AR. Fenofibrate also displays anti-inflammatory properties acting as a negative regulator of genes involved in the inflammatory response. Previous studies reported that FEN lowered the synthesis of acute phase proteins via activation of the nuclear receptor, peroxisome proliferator-activated receptor $\alpha$ $(\operatorname{PPAR} \alpha)($ Delerive et al. 1999; Gervois et al. 2004; Staels et al. 1998). In this study, fenofibrate (FEN) blocked the $\alpha_{1}$ and $\alpha_{2}$-AR-induced upregulating effect on SAA1/2 and SAA3 synthesis, but not that mediated by $\beta_{1 / 2}$-AR. Moreover, when combined to $\alpha_{1} / \alpha_{2}$-AR agonist, FEN blocked the hepatic SAA1/2 and SAA3 upregulation, a fact that has been mainly correlated with the suppression of serum IL- $1 \beta$ and IL- 6 concentrations. It should be noted that, despite the suppression of serum IL- $1 \beta$, IL- 6 , and TNF $\alpha$ levels, FEN did not prevent the Isop-induced SAA upregulation, indicating that potentially, there is no crosstalk between the $\beta$ AR-induced SAA upregulation and $\operatorname{PPAR} \alpha$, cytokines, or 


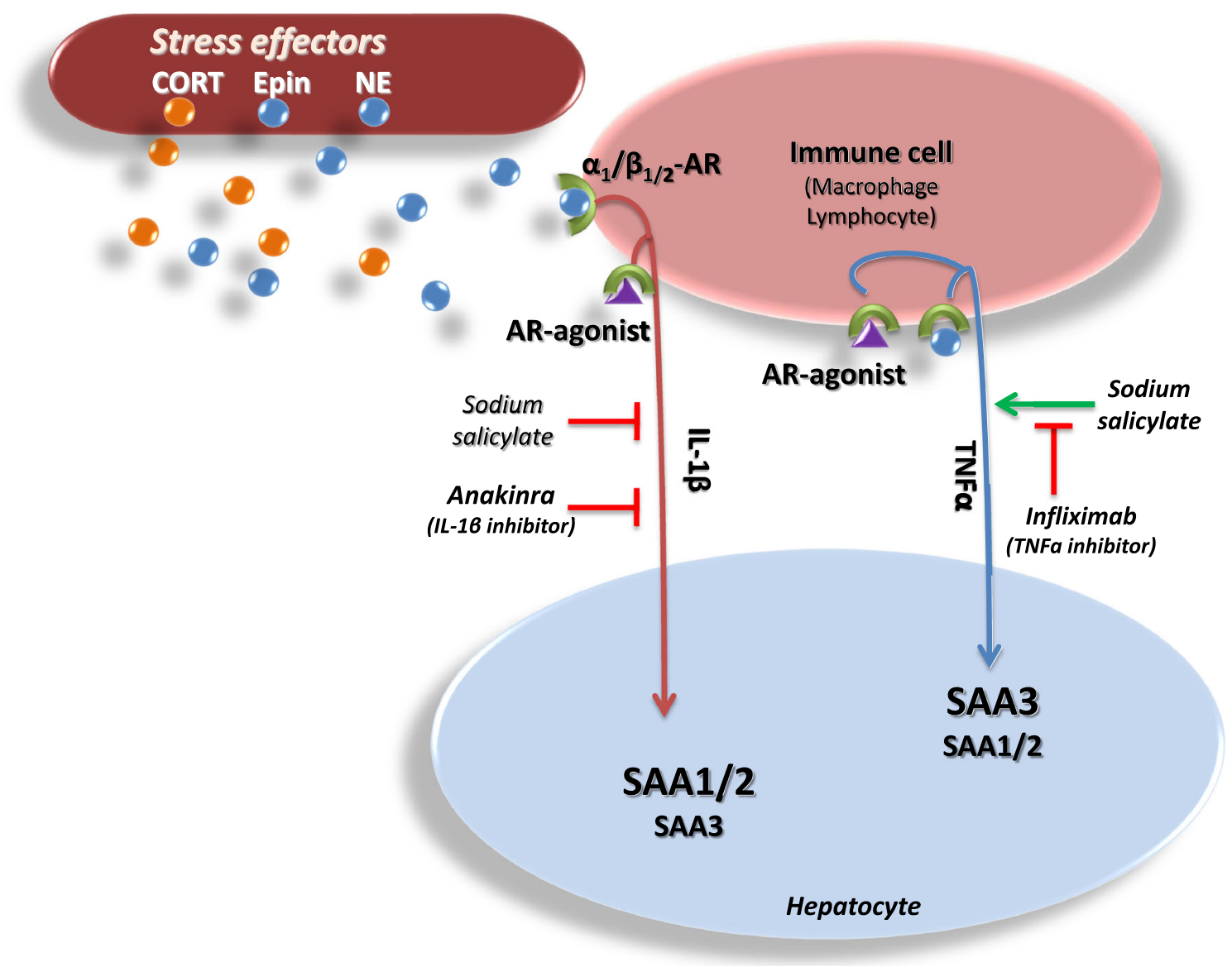

Fig. 5 Hypothetical model summarizing the impact of stress and different ARs on serum A amyloid (SAA) synthesis. Exposure to repeated restraint stress or its effectors, such as epinephrine (Epin) and norepinephrine (NE), stimulate different adrenoceptors (AR) expressed in the immune cells (e.g., macrophage and lymphocytes) that in turn, stimulate the release of pro-inflammatory cytokines, IL- $1 \beta$, IL- 6 , and TNF $\alpha$, which trigger the synthesis of SAA1/2 and SAA3 in the liver of mice. In particular, a significant role for $\alpha_{1}$ - and $\beta_{1 / 2}$-AR is primarily suggested in the induction of SAA1/2 that may involve the release of IL- $1 \beta$, as drugs with anti-inflammatory properties, such as sodium salicylate, as well as the IL- $1 \beta$ inhibitor Anakinra blocked this AR-related SAA1/2 induction. Notably, sodium salicylate further enhanced the SAA3 induction by $\alpha_{1}$-AR agonists, in a TNF $\alpha$-dependent manner supporting an interrelated balance in SAA proteins under AR stimulation other FEN-related pathways. Interestingly, the FEN-induced blockade of the $\alpha_{1}$-AR stimulated $S A A$ expression in the liver, was accompanied with the activation of Erk1/2 and Aktrelated signaling pathways, which display a negative control on SAA regulation (Fasshauer et al. 2004; Nguyen and Gao 1999). The sodium salicylate repressive impact on $\beta_{1 / 2}$-ARdriven SAA1/2 synthesis, could be also explained on the basis of the negative control of PI3k/Akt signaling pathway on SAA synthesis (Fasshauer et al. 2004; Lu et al. 2013; Nguyen and Gao 1999) as the combined treatment of sodium salicylate and the $\beta_{1 / 2}$-AR agonist, Isop, markedly increased Akt phosphorylation compared to that of Isop alone. The observed reduced activation of Erk1/2 signaling in the liver of mice under this combined treatment, appears not to effectively eliminate the down-regulating effect on SAA1/2 triggered by the activation of Akt.

Interestingly, the mechanisms regulating SAA3 seem to be different from those regulating the production and secretion of SAA1/2 (see also Fig. 5). In contrast to SAA $1 / 2$, administration of sodium salicylate simultaneously with AR agonists, mainly with $\mathrm{Ph}\left(\alpha_{1}\right.$-AR agonist), led to a robust induction of hepatic $S A A 3$ expression. This effect is profoundly triggered by TNF $\alpha$ that was highly elevated in serum, potentially via the sodium salicylate-induced inhibition of COX2 (Taupin et al. 1993). Notably, inhibition of TNF $\alpha$ by Infliximab blocked the upregulating effect of the combined treatment using AR agonist and sodium salicylate on SAA3, underscoring the involvement of TNF $\alpha$ in this regulatory pathway. This effect is of a paramount significance as SAA3 is not only a well-known acute phase reactant, but also a molecular link between insulin resistance, obesity, and cardiovascular disease (Fasshauer et al. 2004). Future studies should clarify the presence (or not) of a cross-talk or counterbalance between SAA1/2 and SAA3 production.

The present study investigated the effect of stress, a major activator of SNS, on the regulation of SAA in the liver focusing on adrenoceptor (AR)-linked pathways, major components of the sympathoadrenal response to stress and targets 
of drugs used for the treatment of hypertension, asthma, angina pectoris, heart failure, arrhythmias, prostatic hypertrophy, glaucoma, and depression (Lalchandani et al. 2004; Minneman and Esbenshade 1994; Virtanen 1989). Thus, the findings of this study are of particular interest as indicate that individuals repeatedly exposed to stress or treated with drugs with sympathomimetic properties or directly targeting AR (mainly those of $\alpha_{1}$ - and $\beta_{1 / 2}$-AR subtype), could exhibit increased SAA synthesis in the liver, mediated by proinflammatory cytokines (see Fig. 5). The stress and ARinduced SAA1/2 upregulation can be prevented, in most cases, by anti-inflammatory drugs. However, it should be noted that the combined treatment using AR agonists and the anti-inflammatory drug, sodium salicylate, could dramatically increase $S A A 3$ expression in the liver, triggered by the increased TNF $\alpha$ release. In the long run, the increased production and secretion of SAA could be connected with important pathogenic precipitants of different disease states related to stressful conditions, such as cardiovascular disorders.

Acknowledgments The authors would like to thank Dr. Kristopher Krautz for his valuable technical assistance and support and Dr. Konstantinos Ritis, Professor of Immunology, for his constructive comments on these studies.

Author contributions MK designed the experiments; MK, TM, FM, AK, and CA conducted experiments; MK, IS, and FJG performed data quantification and analysis; MK and IS wrote the manuscript, while FJG was involved in the manuscript revision.

Funding This research was supported by the European Union (European Regional Development Fund- ERDF) and the Greek national funds through the Operational Program "THESSALY- MAINLAND GREECE AND EPIRUS-2007-2013" of the National Strategic Reference Framework (NSRF 2007-2013, Grant 346985/80753) and the National Cancer Institute Intramural Research Program.

\section{Compliance with ethical standards}

Conflict of interest The authors declare that they have no conflicts of interest.

Publisher's Note Springer Nature remains neutral with regard to jurisdictional claims in published maps and institutional affiliations.

\section{References}

Aich P, Potter AA, Griebel PJ (2009) Modern approaches to understanding stress and disease susceptibility: a review with special emphasis on respiratory disease. Int J Gen Med 2:19-32

Artl A, Marsche G, Lestavel S, Sattler W, Malle E (2000) Role of serum amyloid A during metabolism of acute-phase HDL by macrophages. Arterioscler Thromb Vasc Biol 20:763-772

Barneda-Zahonero B, Minano-Molina A, Badiola N, Fado R, Xifro X, Saura CA, Rodriguez-Alvarez J (2009) Bone morphogenetic protein- 6 promotes cerebellar granule neurons survival by activation of the MEK/ERK/CREB pathway. Mol Biol Cell 20:5051-5063
Bryleva EY, Keaton SA, Grit J, Madaj Z, Sauro-Nagendra A, Smart L, Halstead S, Achtyes E, Brundin L (2017) The acute-phase mediator serum amyloid A is associated with symptoms of depression and fatigue. Acta Psychiatr Scand 135:409-418

Chrousos GP (2009) Stress and disorders of the stress system. Nat Rev Endocrinol 5:374-381

Collier CT, Williams PN, Carroll JA, Welsh THJ, Laurenz JC (2011) Effect of maternal restraint stress during gestation on temporal lipopolysaccharide-induced neuroendocrine and immune responses of progeny. Domest Anim Endocrinol 40:40-50

Cooper JR, Bloom FE (1996) The biochemical basis of neuropharmacology, 7th edn. Oxford University Press, New York

Cray C, Dickey M, Brewer LB, Arheart KL (2013) Assessement of serum amyloid A levels in the rehabilitation setting in the Florida manatee (Trichechus manatus latirostris). J Zoo Wildl Med 44:911-917

Cruise JL, Knechtle SJ, Bollinger RR, Kuhn C, Michalopoulos G (1987) Alpha 1-adrenergic effects and liver regeneration. Hepatology 7: 1189-1194

Delerive P, De Bosscher K, Besnard S, Vanden Berghe W, Peters JM, Gonzalez FJ, Fruchart JC, Tedgui A, Haegeman G, Staels B (1999) Peroxisome proliferator-activated receptor alpha negatively regulates the vascular inflammatory gene response by negative crosstalk with transcription factors NF-kappaB and AP-1. J Biol Chem 274:32048-32054

Dong Z, Wu T, Qin W, An C, Wang Z, Zhang M, Zhang Y, Zhang C, An F (2011) Serum amyloid A directly accelerates the progression of atherosclerosis in apolipoprotein E-deficient mice. Mol Med 17: $1357-1364$

Elenkov IJ, Wilder RL, Chrousos GP, Vizi ES (2000) The sympathetic nerve - an integrative interface between two supersystems: the brain and the immune system. Pharmacol Rev 52:595-638

Fabbri E, Moon TW (2016) Adrenergic signaling in teleost fish liver, a challenging path. Comp Biochem Physiol B Biochem Mol Biol 199: $74-86$

Fasshauer M, Klein J, Kralisch S, Klier M, Lossner U, Bluher M, Paschke $R$ (2004) Serum amyloid A3 expression is stimulated by dexamethasone and interleukin-6 in 3T3-L1 adipocytes. J Endocrinol 183: 561-567

Flierl MA, Rittirsch D, Nadeau BA, Chen AJ, Sarma JV, Zetoune FS, McGuire SR, List RP, Day DE, Hoesel LM, Gao H, Van Rooijen N, Huber-Lang MS, Neubig RR, Ward PA (2007) Phagocyte-derived catecholamines enhance acute inflammatory injury. Nature 449: 721-725

Flierl MA, Rittirsch D, Huber-Lang M, Sarma JV, Ward PA (2008) Catecholamines-crafty weapons in the inflammatory arsenal of immune/inflammatory cells or opening pandora's box? Mol Med 14:195-204

Flierl MA, Rittirsch D, Nadeau BA, Sarma JV, Day DE, Lentsch AB, Huber-Lang MS, Ward PA (2009) Upregulation of phagocytederived catecholamines augments the acute inflammatory response. PLoS One 4:e4414

Furchgott RF (1972) The classification of adrenoceptors (adrenergic receptors). An evaluation from the standpoint of receptor theory. In: Blaschko H, Muecholl E (eds) Catecholamines. Springer-Verlag, New York, p 283-335

Gabay C, Kushner I (1999) Acute-phase proteins and other systemic responses to inflammation. N Engl J Med 340:448-454

Gervois P, Kleemann R, Pilon A, Percevault F, Koenig W, Staels B, Kooistra T (2004) Global suppression of IL-6-induced acute phase response gene expression after chronic in vivo treatment with the peroxisome proliferator-activated receptor-alpha activator fenofibrate. J Biol Chem 279:16154-16160

Ghezzi P, Sipe JD (1988) Dexamethasone modulation of LPS, IL-1, and TNF stimulated serum amyloid a synthesis in mice. Lymphokine Res 7:157-166 
Housby JN, Cahill CM, Chu B, Prevelige R, Bickford K, Stevenson MA, Calderwood SK (1999) Non-steroidal anti-inflammatory drugs inhibit the expression of cytokines and induce HSP70 in human monocytes. Cytokine 11:347-358

Husebekk A, Skogen B, Husby G, Marhaug G (1985) Transformation of amyloid precursor SAA to protein AA and incorporation in amyloid fibrils in vivo. Scand J Immunol 21:283-287

Jacobsen S, Andersen PH (2007) The acute phase protein serum amyloid A (SAA) as a marker of inflammation in horses. Equine Vet Educ 19:38-46

Jayaraman S, Gantz DL, Haupt C, Gursky O (2017) Serum amyloid A forms stable oligomers that disrupt vesicles at lysosomal $\mathrm{pH}$ and contribute to the pathogenesis of reactive amyloidosis. Proc Natl Acad Sci U S A 114:E6507-E6515

Johnson EO, Kamilaris TC, Chrousos GP, Gold PW (1992) Mechanisms of stress: a dynamic overview of hormonal and behavioral homeostasis. Neurosci Biobehav Rev 16:115-130

Johnson BD, Kip KE, Marroquin OC, Ridker PM, Kelsey SF, Shaw LJ, Pepine CJ, Sharaf B, Bairey Merz CN, Sopko G, Olson MB, Reis SE (2004) Serum amyloid A as a predictor of coronary artery disease and cardiovascular outcome in women: the National Heart, Lung, and Blood Institute-sponsored Women's Ischemia Syndrome Evaluation (WISE). Circulation 109:726-732

Johnson JD, Campisi J, Sharkey CM, Kennedy SL, Nickerson M, Greenwood BN, Fleshner M (2005) Catecholamines mediate stress-induced increases in peripheral and central inflammatory cytokines. Neuroscience 135:1295-1307

Kingman A, Pereira NL (2001) Cardiac amyloidosis. J S C Med Assoc 97:201-206

Kisilevsky R (1983) Amyloidosis: a familiar problem in the light of current pathogenetic developments. Lab Investig 49:381-390

Konstandi M, Johnson EO, Marselos M, Kostakis D, Fotopoulos A, Lang MA (2004) Stress-mediated modulation of B(alpha)P-induced hepatic CYP1A1: role of catecholamines. Chem Biol Interact 147:6577

Lalchandani SG, Zhang X, Hong SS, Liggett SB, Li W, Moore BM 2nd, Miller DD, Feller DR (2004) Medetomidine analogs as selective agonists for the human alpha2-adrenoceptors. Biochem Pharmacol 67:87-96

Langer SZ (2015) Alpha2-adrenoceptors in the treatment of major neuropsychiatric disorders. Trends Pharmacol Sci 36:196-202

Lee HJ, Kim JH, Kim SW, Joo HA, Lee HW, Kim YS, Park SJ, Hong SP, Kim TI, Kim WH, Kim YH, Cheon JH (2017) Proteomic analysis of serum amyloid A as a potential marker in intestinal Behcet's disease. Dig Dis Sci 62:1953-1962

Lohse MJ (2015) The ins and outs of adrenergic signaling. J Mol Med (Berl) 93:955-962

Lu J, Liang J, Wang JR, Hu L, Tu Y, Guo JY (2013) Acupuncture activates ERK-CREB pathway in rats exposed to chronic unpredictable mild stress. Evid Based Complement Alternat Med 2013:469765

Ma J, Yee A, Brewer HB Jr, Das S, Potter H (1994) Amyloid-associated proteins alpha 1-antichymotrypsin and apolipoprotein $\mathrm{E}$ promote assembly of Alzheimer beta-protein into filaments. Nature 372:9294

Madden KS, Felten SY, Felten DL, Sundaresan PR, Livnat S (1989) Sympathetic neural modulation of the immune system. I Depression of $\mathrm{T}$ cell immunity in vivo and vitro following chemical sympathectomy. Brain Behav Immun 3:72-89

Malle E, De Beer FC (1996) Human serum amyloid A (SAA) protein: a prominent acute-phase reactant for clinical practice. Eur J Clin Investig 26:427-435

Marzi C, Huth C, Herder C, Baumert J, Thorand B, Rathmann W, Meisinger C, Wichmann HE, Roden M, Peters A, Grallert H, Koenig W, Illig T (2013) Acute-phase serum amyloid A protein and its implication in the development of type 2 diabetes in the KORA S4/F4 study. Diabetes Care 36:1321-1326
McConnell KJ, Olson KL, Delate T, Merenich JA (2009) Factors associated with recurrent coronary events among patients with cardiovascular disease. Pharmacotherapy 29:906-913

Minneman KP, Esbenshade TA (1994) Alpha 1-adrenergic receptor subtypes. Annu Rev Pharmacol Toxicol 34:117-133

Miyazaki Y, Katanasaka Y, Sunagawa Y, Hirano-Sunagawa S, Funamoto M, Morimoto E, Komiyama M, Shimatsu A, Satoh-Asahara N, Yamakage H, Wada H, Hasegawa K, Morimoto T (2016) Effect of statins on atherogenic serum amyloid a and alpha1-antitrypsin lowdensity lipoprotein complexes. Int J Cardiol 225:332-336

Nguyen VA, Gao B (1999) Cross-talk between alpha(1B)-adrenergic receptor (alpha(1B)AR) and interleukin-6 (IL-6) signaling pathways. Activation of alpha(1b)AR inhibits il-6-activated STAT3 in hepatic cells by a $42 / 44$ mitogen-activated protein kinase-dependent mechanism. J Biol Chem 274:35492-35498

Nicolaides NC, Kyratzi E, Lamprokostopoulou A, Chrousos GP, Charmandari E (2015) Stress, the stress system and the role of glucocorticoids. Neuroimmunomodulation 22:6-19

Nishi S, Alchi B, Imai N, Gejyo F (2008) New advances in renal amyloidosis. Clin Exp Nephrol 12:93-101

O’Brien KD, McDonald TO, Kunjathoor V, Eng K, Knopp EA, Lewis K, Lopez R, Kirk EA, Chait A, Wight TN, deBeer FC, LeBoeuf RC (2005) Serum amyloid A and lipoprotein retention in murine models of atherosclerosis. Arterioscler Thromb Vasc Biol 25:785-790

O'Brien K, Fitzgerald DC, Naiken K, Alugupalli KR, Rostami AM, Gran B (2008) Role of the innate immune system in autoimmune inflammatory demyelination. Curr Med Chem 15:1105-1115

Pettersson T, Konttinen YT, Maury CP (2008) Treatment strategies for amyloid A amyloidosis. Expert Opin Pharmacother 9:2117-2128

Ridker PM, Cushman M, Stampfer MJ, Tracy RP, Hennekens CH (1998) Plasma concentration of $\mathrm{C}$-reactive protein and risk of developing peripheral vascular disease. Circulation 97:425-428

Schiller M, Bohm M, Dennler S, Ehrchen JM, Mauviel A (2006) Mitogen- and stress-activated protein kinase 1 is critical for interleukin-1-induced, CREB-mediated, c-fos gene expression in keratinocytes. Oncogene 25:4449-4457

Skogen B, Thorsteinsson L, Natvig JB (1980) Degradation of protein SAA to an AA-like fragment by enzymes of monocytic origin. Scand J Immunol 11:533-540

Sletten K, Husby G (1974) The complete amino-acid sequence of nonimmunoglobulin amyloid fibril protein AS in rheumatoid arthritis. Eur J Biochem 41:117-125

Spengler RN, Allen RM, Remick DG, Strieter RM, Kunkel SL (1990) Stimulation of alpha-adrenergic receptor augments the production of macrophage-derived tumor necrosis factor. J Immunol 145:1430 1434

Spengler RN, Chensue SW, Giacherio DA, Blenk N, Kunkel SL (1994) Endogenous norepinephrine regulates tumor necrosis factor-alpha production from macrophages in vitro. J Immunol 152:3024-3031

Staels B, Koenig W, Habib A, Merval R, Lebret M, Torra IP, Delerive P, Fadel A, Chinetti G, Fruchart JC, Najib J, Maclouf J, Tedgui A (1998) Activation of human aortic smooth-muscle cells is inhibited by PPARalpha but not by PPARgamma activators. Nature 393:790 793

Steel DM, Whitehead AS (1994) The major acute phase reactants: Creactive protein, serum amyloid $\mathrm{P}$ component and serum amyloid a protein. Immunol Today $15: 81-88$

Sternberg EM (2006) Neural regulation of innate immunity: a coordinated nonspecific host response to pathogens. Nat Rev Immunol 6: 318-328

Tan KS, Nackley AG, Satterfield K, Maixner W, Diatchenko L, Flood PM (2007) Beta2 adrenergic receptor activation stimulates proinflammatory cytokine production in macrophages via PKA- and NF-kappaB-independent mechanisms. Cell Signal 19:251-260

Taupin V, Gogusev J, Descampslatscha B, Zavala F (1993) Modulation of tumor-necrosis-factor-alpha, interleukin-1-beta, interleukin-6, 
interleukin-8, and granulocyte/macrophage colony-stimulating factor expression in human monocytes by an endogenous anxiogenic benzodiazepine ligand, triakontatetraneuropeptide - evidence for a role of prostaglandins. Mol Pharmacol 43:64-69

Tracey KJ (2002) The inflammatory reflex. Nature 420:853-859

Turlo A, Cywinska A, Czopowicz M, Witkowski L, Niedzwiedz A, Slowikowska M, Borowicz H, Jaskiewicz A, Winnicka A (2015) The effect of different types of musculoskeletal injuries on blood concentration of serum amyloid A in thoroughbred racehorses. PLoS One 10:e0140673

Uhlar CM, Whitehead AS (1999) Serum amyloid A, the major vertebrate acute-phase reactant. Eur J Biochem 265:501-523

Virtanen R (1989) Pharmacological profiles of medetomidine and its antagonist, atipamezole. Acta Vet Scand Suppl 85:29-37

Vittimberga FJ Jr, McDade TP, Perugini RA, Callery MP (1999) Sodium salicylate inhibits macrophage TNF-alpha production and alters MAPK activation. J Surg Res 84:143-149
Won TW (2013) Fenofibrate, a peroxisome proliferator-activated receptor alpha-agonist, blocks lipopolysaccharide-induced inflammatory pathways in mouse liver. Korean J Hepatobiliary Pancreat Surg 17:89-108

Yamazaki K, Kuromitsu J, Tanaka I (2002) Microarray analysis of gene expression changes in mouse liver induced by peroxisome proliferator-activated receptor alpha agonists. Biochem Biophys Res Commun 290:1114-1122

Ye RD, Sun L (2015) Emerging functions of serum amyloid A in inflammation. J Leukoc Biol 98:923-929

Zhang N, Ahsan MH, Purchio AF, West DB (2005) Serum amyloid Aluciferase transgenic mice: response to sepsis, acute arthritis, and contact hypersensitivity and the effects of proteasome inhibition. J Immunol 174:8125-8134 